\title{
Tarjoa käsikirjoitusta teemaan!
}

\author{
Aikuiskasvatus katsoo laajasti yhteiskuntaan.
}

\section{AIKUISKOULUTUSPOLITIIKKA, 4/2020}

Vielä ehdit lähettää näkökulman ja puheenvuoron teemanumeroon, jossa pureudutaan kriittisellä otteella aikuiskoulutuspolitiikan eri ulottuvuuksiin, kuten miten aikuiskoulutusta koskevia päätöksiä tehdään, miten syntyvät linjaukset aikuisten kouluttamiseksi ja mitä aikuiskoulutuspolitiikalla tuotetaan.

Aikataulu: Lähetä käsikirjoitus viimeistään 7. elokuuta. IImestyy joulukuussa 2020.

Toimituskunnassa numerosta vastaa Nina Haltia.

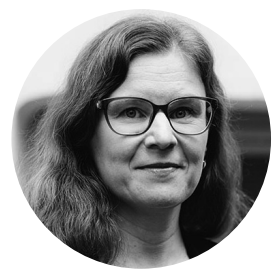

\section{SIVISTYSTYÖ PLANETAARISTEN} KRIISIEN AJASSA, 2/2021

Miten sivistystyö voisi edistää sosiaalista, taloudellista ja ekologista kestävyyttä? Ekososiaalista sivistystä tarkastellaan planetaarisuuden ja kestävän kehityksen näkökulmista. Teemanumero juhlistaa Sivistystyön vapaus ja vastuu (SVV) -ohjelman kymmenvuotisuutta. Käsikirjoituksia pyydetään aikuiskasvatusalan toimijoiden ohella köyhyys-, yhteiskunta-, ilmasto-, ympäristö- sekä media-alan asiantuntijoilta.

\begin{abstract}
Aikataulu: Lähetä tiedeartikkelin käsikirjoitus viimeistään 14 . syyskuuta. Ilmestyy kesäkuussa 2021.

Toimituskunnassa numerosta vastaa Hanna Toiviainen.
\end{abstract}

\author{
TUTKIJA JA AKTIVISTI, 1/2022
}

Tutkimusta tehdään, jotta ymmärretään paremmin todellisuutta. Joskus lisääntynyt ymmärrys saattaa johtaa siihen, että vallalla oleva kehityskulku pitää kääntää. Teemanumerossa paneudutaan tutkijan ja aktivistin roolien väliseen jännitteeseen. Tutkimuksen poliittisuus, vahvistuva eettisyyden tarve monimutkaistuneessa maailmassa ja dystooppiset tulevaisuuskuvat vaativat tutkijaa asemoitumaan uudella tavalla yhteiskunnassa. Näkökulmana aktivismiin voi olla esimerkiksi elämän edellytysten jatkuminen, tasa-arvon kysymykset tai aktiivinen kansalaisuus. Käsikirjoitukset voivat olla yhtä hyvin aikuiskasvatuksen ytimessä kuin tieteiden rajat ylittäviä, teoreettisia, käsitteellisiä tai empiirisiä.

Aikataulu: Lähetä tiedeartikkelin käsikirjoitus viimeistään 20. huhtikuuta 2021. Näkökulmat, puheenvuorot ja kirja-arviot ehtivät mukaan elokuussa 2021. Ilmestyy maaliskuussa 2022.

Toimituskunnassa numerosta

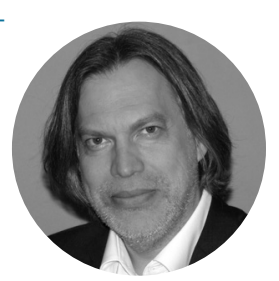
vastaa Arto O. Salonen.

\section{NÄIN TARJOAT KÄSIKIRJOITUSTA TEEMANUMEROON}

- Lue kirjoittajaohjeet

- Kerro, miksi käsikirjoituksesi on ajankohtainen juuri nyt ja minkä asian haluat sillä tuoda keskusteluun.

- Meilaa käsikirjoitus toimitukseen (terhi. kouvo@kvs.fi).

\section{Lisätiedot:}

toimituspäällikkö Terhi Kouvo, 0400396 437, terhi.kouvo@kvs.fi 